\title{
Oil, Wheat and Currencies ${ }^{1}$
}

\section{Elena Flor}

A study carried out by Robert Triffin International (RTI, 2014) entitled Using the SDR as a Lever to Reform the International Monetary System, supplementing the Palais Royal Initiative presented at the G20 in 2011, has showed that the trend towards a multi-currency monetary system requires cooperation between the IMF and central banks. The first step in this trend came to fruition on October $1^{\text {st }}$ last year with the inclusion of the renminbi in the SDR basket. The second step, consisting in extending SDR issuance not only for Official SDRs but also for Market SDRs - as happened with the ECU before the creation of the euro-, was first implemented with the World Bank's SDR two billion (USD 2.8 billion) issuance programme on the Chinese market. This was made in agreement with the People's Bank of China, and the first tranche, equal to SDR 500 million (USD 700 million), was issued in September 2016. Therefore, the World Bank's SDR issuance provides a diversification opportunity for China's and other countries' savings and investment opportunities in renminbi.

The SDR basket tends to represent the real economic weight of the different economies. Today, its component currencies already account for about $60 \%$ of world GDP and $90 \%$ of exports. In five years the basket will be revised, and it is likely that the inclusion of other currencies such as the rupee and the ruble will further increase the ability of the SDR to represent the entire world economy and be the first essential tool for the governance of globalisation.

The extended use of the SDRin official reserves, financial markets and as a unit of account, will also allow the problem of commodity pricing to be addressed with concrete prospects for a solution. The RTI undertook a study of the price evolution from 2000 to 2016 of two key commodities, oil and wheat, to ascertain the influence of the exchange rate on the overall variability of the prices of these goods ${ }^{2}$.

First, the negative correlation between the dollar exchange rate and the prices in question is clear: if the value of the dollar decreases, prices rise and vice versa. In addition, the simulation, for the same period, of the quotation in a supranational currency such as the SDR shows that it would reduce market speculation and price variability. Their prices would be more stable because the denomination in SDR, with a defined value in terms of major currencies, would diversify the foreign exchange risk. The quotation in euro would achieve better results than in dollar and worse results than in SDR.

All commodities are quoted in dollars, then ceteris paribus (i.e. if their dollar price and the price of manufactured goods produced by the different national economies, bearing the related costs in their own currency, did not change), any changes in the valuation of the dollar would directly influence the terms of trade between the United States and other countries and would have an impact on income distribution as well.

On the demand side, a devaluation of the dollar would reduce the price of commodities in national currency for importing countries 
with floating exchange rate regimes, such as Europe or Japan, thus increasing their income and demand. The effect would be neutral for countries that have pegged their currency to the dollar, as China had been doing until July 2005.

On the supply side, the effects of the depreciation of the dollar on the costs of producing countries would be less noticeable, since they mainly adopt exchange rate regimes pegged to the dollar.

In the short term, the slight price elasticity of both demand and supply prevents major adjustments; therefore, speculation targets futures markets. When the dollar depreciates, commodities attract investors who discount future inflation and protect themselves from the weakening of the dollar. This results in the growing financialisation of goods, starting with oil, which is a contributory cause of the negative correlation between their price and the value of the dollar.
In the long term, outcomes depend on market power. Exporters will attempt to raise prices to offset the devaluation of the dollar, whereas supply and demand will become more elastic because there will be enough time to plan investments to increase production capacity and/or look for substitutes for the goods under pressure, thereby reducing their consumption.

In conclusion, it can be said that, on average and ceteris paribus, the devaluation of the dollar tends to reduce the price of oil in consuming countries and to increase real income and demand, which in turn leads to an increase-albeit delayed-in prices. Conversely, in a situation where the dollar is strong and oil prices are weak only the dollar area benefits from lower energy costs because, in other importing countries, they are offset - at least in part - by the exchange rate of the currency used for pricing. This example demonstrates the utility, in terms of transaction costs, stability and equity, of pricing in SDR.

\section{1: Trend in oil prices per barrel in US dollar, euro and SDR (2000-2016)}

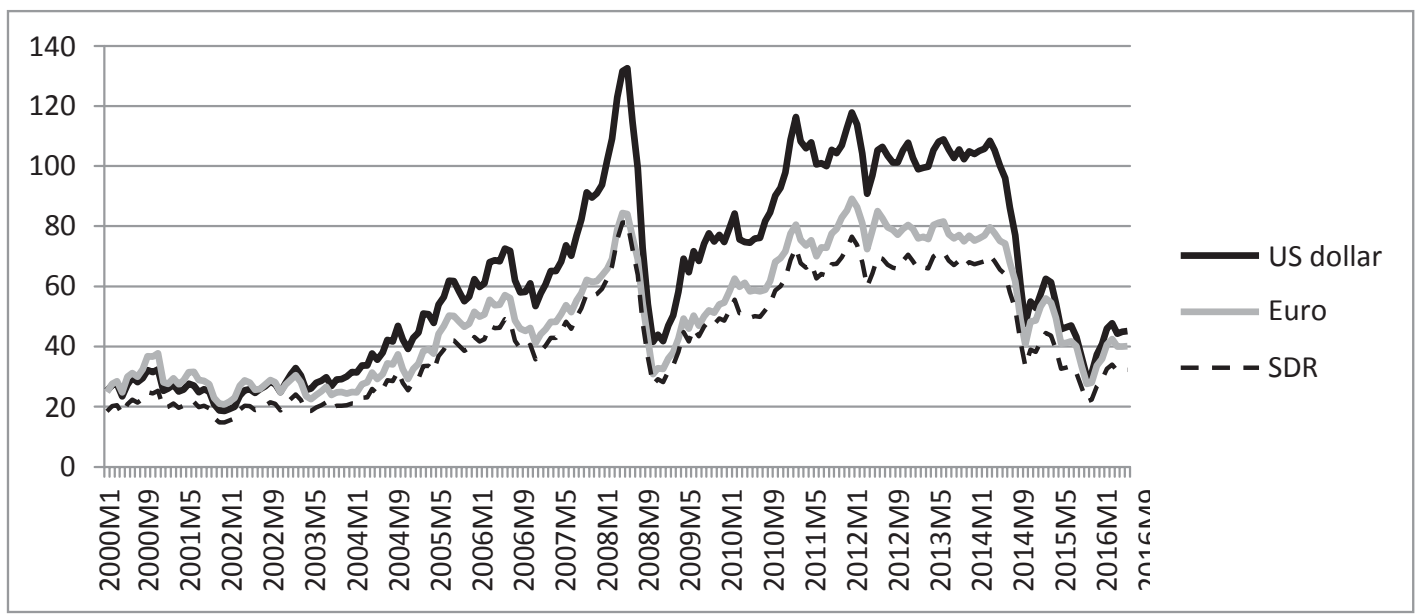

The price for crude oil (petroleum) in US dollars is the simple average of three spot prices: Dated Brent, West Texas Intermediate and the Dubai Fateh. Source: IMF

For an effective comparison, the price of an oil barrel expressed in USD has been converted into euro and SDR, using the monthly rate. Source: IMF and European Commission. 


\section{Comments}

2: Trend in wheat prices per metric ton in US dollar, euro and SDR (2000-2016)

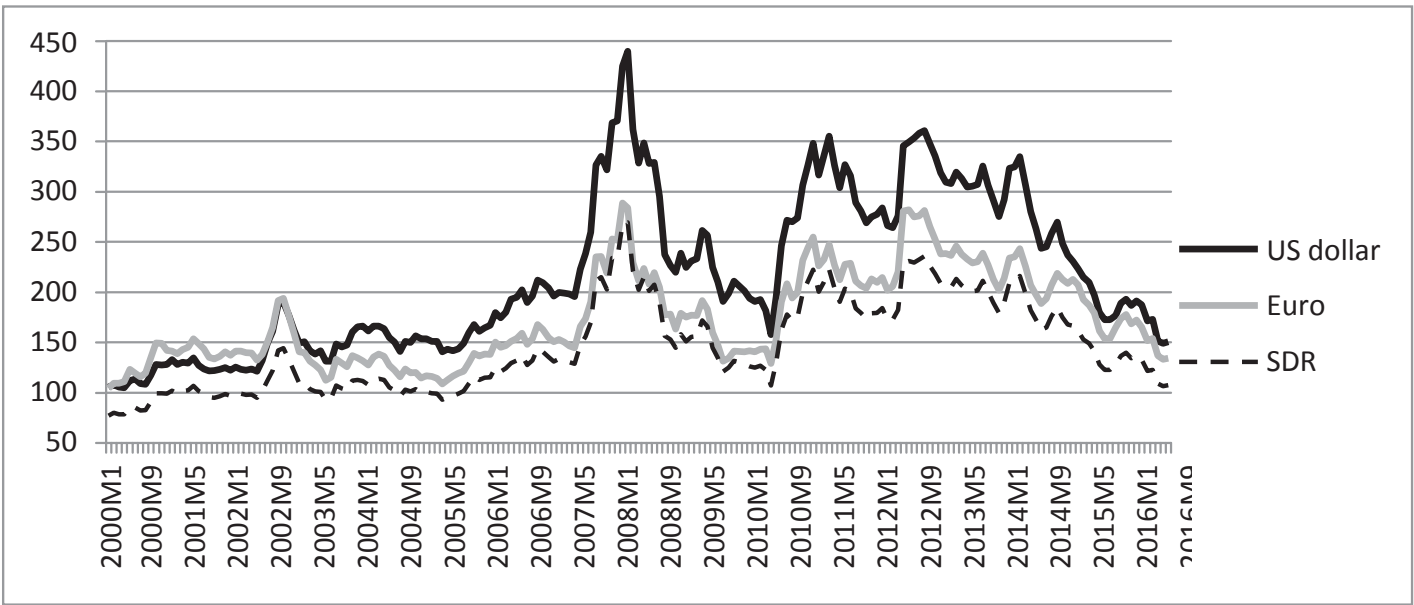

Wheat, No.1 Hard Red Winter, ordinary protein, FOB Gulf of Mexico, USD per metric ton.

For an effective comparison, the price of wheat has been converted into euro and SDR using the monthly rate.

Source: IMF and European Commission.

${ }^{1}$ This article has been published on April 2017 as No 2 of SDR Notes by Robert Triffin International (RTI).

${ }^{2}$ Valentina Tosolini, Analysing Commodity Prices: Trend for Crude oil and Wheat in US Dollars, Euro and Special Drawing Rights (SDR), Torino 2016 (RTI). 